\title{
Jamaah kraton: the Muslim new agers from Pekalongan
}

\author{
Noor Aida \\ Centerfor Rel igious and Cross-cultural Stud ies, Graduate School, \\ Gadjah Mada University \\ E-mail:aidavyasa@yahoo.com
}

\begin{abstract}
The objective of this research was to know Muslim New Age identity, how the New Age practitioners identify themselves as Muslim and apply religiosity, attitude and expression in their personal and social life. This research discusses about the religious experiences perceived by those practitioners of Shamballa Multi Dimension Healing.

It was a qualitative research using analytical descriptive method, in which the researcher tried to describe the Muslim New Agers identity by explaining their ritual and their perception about their religion and tradition. The location of this research was in Pekalongan, because it is a good example to describe how New Age impact to religion and tradition by describing how some Arabian Moslem Pekalongan conducted some New Age activities.

The research finding shows that Jamaah Kraton from Pekalongan feel comfortable with New Age because of two main reasons: the fascinating teaching and the charismatic leader. Moreover, they able to negotiate their religious identity problem by passing over and mixed all religion's teaching which has no contrary with their main religion and tradition, Islam and Arab tradition. If they find any contradiction (in common definition of other Muslim), they will not feel that they conduct heresy, and the comfort ability they had picturing of a 'merger and crossover', 'a creation of a mixed cultures and' and 'syncretism'.
\end{abstract}


Di Indonesia, terutama sejak awal 1990-an, kita menyaksikan penuhnya tempat kajian tasawuf dan maraknya buku-buku tentang ini. Bahkan fenomena bangkitnya spiritualitas ini sudah pula memasuki kalangan profesional dan bisnis, berkat kehadiran KH Abdullah Gymnastiar (Aa Gym) dengan Manajemen Qolbu, atau M. Arifin Ilham dengan gerakan zikir, atau Ary Ginandjar dengan pelatihan ESQ. Teknik reiki dan meditasi modern seperti Anand Asram dan Brahma Kumaris juga digemari di kalangan kaum muda dan paruh baya, tidak terkecuali dengan Reiki Shamballa yang tergolong baru di Indonesia, juga berkembang pesat di sebuah kota kecil, Pekalongan. Teknik ini dikombinasikan dengan sufisme Islam oleh Jamaah Kraton, sebuah grup diskusi Islam di Pekalongan.

Subyek penelitian ini adalah sejumlah anggota dan penggerak dari Jamaah Kraton yang sudah melangsungkan diskusi dan latihan meditasinya selama bertahuntahun. Kebanyakan anggotanya adalah Arab keturunan yang sudah lama hidup di Indonesia. Pengumpulan data dilakukan dengan wawancara dan observasi mendalam selama beberapa bulan di Pekalongan. Penelitian ini berguna untuk memberikan batasan tentang identitas seorang Muslim yang melakukan spiritualitas New Age. Pada dasarnya penelitian ini untuk melihat kegiatan religius dan juga memaparkan pandangan keberagamaan anggota Jamaah Kraton sebagai seorang Arab, Muslim, dan praktisi New Age.

Hasil penelitian menunjukkan bahwa seorang Arab dan Muslim New Age pada awalnya merupakan seorang Muslim dan Arab seperti kebanyakan. Ketika dihadapkan dengan keragaman yang ada, mereka mengambil sikap negosiasi, dan melakukan passing over serta membentuk identitas hybrid. Dengan cara ini mereka merasa bahwa Islam yang mereka yakini adalah Islam yang dikehendaki oleh Nabi Muhammad. Penelitian ini juga menemukan bahwa agama dan tradisi mereka membentuk identitas mereka sebagai seorang yang universal inklusif.

Keywords: New Age; Reiki; Meditation; Sufism; Hybrid

\section{Introduction}

The term New Age $^{1}$ in the West refers to a green social phenomenon and socio-religious movement developed around the 70's and

\footnotetext{
${ }^{1} \mathrm{New}$ Age is a cultic milieu which consists of a blend of eastern mysticism, neo-paganism, western esotericism, occult phenomena, dealt with charismatic personality who is divinely in
} 
80 's, where they share many ideas with the ecology, conservation, environmental, feminist, peace movements, democracy and ecological issues which is concerned with civil liberties, social justice and nonviolence. In January, 1976, Marilyn Ferguson published an editorial, "The Movement That Has No Name".

What she meant by 'it' is, 'The Aquarian Conspiracy'; but this 'conspiracy' emerged after the social activism of the 1960's and the 'consciousness revolution of the early 1970 s. $^{2}$ In the early movement, the New Age in Indonesia was triggered by the translation of James Redfield's spiritual novel, The Celestine Prophecy: An Adventure; the spiritual movement of Anand Ashram in early 1999. ${ }^{3}$ In May 25th 1998 , Sukidi published a book about spiritual crisis, and this was followed by many writings about spirituality in Kompas (from 1998-2000) such as: Jalan Menuju tuhan (Road to the Divine), Kearifan Spiritual (Spiritual Wisdom), Membuka Tabir Jantung Agama, New Age, Petualangan Spiritual ke Shambhala (Spiritual Experience to Shambhala), Sembilan Wawasan Manuskrip Celestine (Nine Celestial Manuscript), Shambhala, Pengalaman Spiritual Lintas Agama (Spiritual Experience accros the Religion), Spiritualitas Intelligence, Spiritualitas New Age, The Tao of..., and Spiritualitas Feminis dalam Gerakan New Age. ${ }^{4}$ In 2001, Gramedia publish Sukidi's pocketbook about New Age, New Age: Wisata Spiritualitas

spired, spirits, angels, elementals, channeling, aura, acupuncture, past-life therapy, soul travel, Reiki, aromatherapy, rebirthing, reincarnation, holistic health, green movement, and as social phenomenon, self spirituality and human potential movement are the keys. Brian added that Hannegraaff and Heelas tend to view Neo-paganism as part of New Age Movement since they have same background on rejection of materialism world and orthodoxy of a religious institution of Christianity. See Brian Morris, Religion and Anthropology: A Critical Introduction, New York: Cambridge University Press, 2006, 304-308.

2Marilyn Ferguson, The Aquarian Conspiracy: Personal and Social Transformation in the 1980s, Los Angeles: J.P Tarcher, Inc., 1980, 18.

${ }^{3}$ See Sukidi, Wisata Spiritual Lintas Agama, Jakarta: Gramedia, 2001, 55-57.

4"Spiritualitas Feminis dalam Gerakan New Age", Jurnal Perempuan, no. 20 ( 2001), 7-21. 
Lintas Agama - a compilation of many of his writings about New Age in Kompas. The foreword was written by Anand Krishna, the founder of Anand Ashram, which according to Howell, is the part of the New Age Movement which is now developed in many places such us Solo, Yogyakarta, Semarang, Jakarta, Bali and Bogor. ${ }^{5}$ In his article about New Age in Indonesia, Ahmad Nurcholis stated that the movement arose around the 90's until today, for example Brahma Kumaris, Anand Krisna, and Lia Eden community. ${ }^{6}$ However, according to Julia Howell in her paper, Brahma Kumaris, Anand Krishna and Salamullah were part of the New Age movement in Indonesia, and during Howell's writing, Salamullah had not yet become the Lia Eden Movement like today. ${ }^{7}$ The New Age is not a religion and has no desire to become. It is different from some of mystical movements in Indonesia during the Dutch Colonial period.

Most Muslims in Indonesia embrace the teaching of Sunni though there are lots of Indonesian Muslim also follows the teaching of Shiite. We can find many book publishers and religious foundation based on Shiite Muslim teaching in Indonesia. But, in general, the Muslim community in Indonesia is divided into two orientations: first, the modernist, whom obeyed the orthodox theology which is textual and practiced the modern concept; second, the traditionalist, which followed the charismatic kyai in the Pesantren. Many of the hundreds of political parties launched in the early days of reformasi (in the year of 1999) were specifically Muslim parties, several of whom began calling for a consti-

${ }^{5}$ See JD. Howell, "Islam, The New Age and Marginal Religious in Indonesia: Changing Meanings of Religious Pluralism", The Cesnur 2003 International Conference, Vilnius, Lithuania, 2003.

${ }^{6}$ Ahmad Nurcholish, "Agama Baru itu bernama New Age", Majemuk. No. 20 (Mei-June 2006.), 18.

7JD. Howell, "Islam, The New Age and Marginal Religious in Indonesia: Changing Meanings of Religious Pluralism", The Cesnur 2003 International Conference, Vilnius, Lithuania, 2003. 
tutional amendment to make Indonesia an Islamic state by requiring Muslims to observe Islamic law (syari'ah) (Howell, 2003). Not only that, Indonesia also has Jaringan Islam Liberal (JIL), Hizbut Tahrir Indonesia (HTI), Majelis Mujahidin Indonesia (MMI), and also what has been considered as sects such as Ahmadiyyah, Jamaah Salamullah, Lembaga Dakwah Islam Indonesia (LDII), ${ }^{8}$ and now the New Age in Pekalongan.

Shamballa is a part of the New Age activity. This assumption is based on the similarity between Shamballa teachings and other spiritual movements (eastern based and neo-pagan) such as Theosophy and Reiki. In 1995, it has been believed for the Shamballa practitioners that the Ascended Master Saint Germain through meditation gave attunement of Shamballa to John Armitage or Haridas Melchizedek - a spiritualist and healer famous in America and Europe. The healing method of Shamballa is believed to be a teaching that came from old Atlantis and was brought by Ascended Master Saint Germain. It has been said that Shamballa is not only a healing method but also a way to reach higher-self by developing spiritual intuition. ${ }^{9}$ Since Shamballa contains Esoteric teachings such as Reiki, and Neo-Pagan beliefs, I classified Shamballa as New Age. ${ }^{10}$

The practitioners in Pekalongan considered themselves as Light Workers ${ }^{11}$ and named themselves Jamaah Kraton, since the place of meditation is takes place in Kraton, Pekalongan. All of the active partici-

\footnotetext{
${ }^{8}$ See further information in 'Laporan Kebebasan Beragama Internasional 2006' which is taken from Biro Demokrasi, Hak Asasi Manusia dan Perburuhan.

${ }^{9}$ Channeled at March 16, 1996 by HariDas from Ascended Master Germain and rewrote in guide-book of Shamballa Multi Dimension Healing Level 1.

${ }^{10}$ David V. Barret, Sects, 'Cults' and Alternative Religions: a World Survey and Sourcebook. London: Blanford, 1996, 230.

${ }^{11}$ They called themselves as Pekerja Cahaya or in international New Age term is known as Light Workers.
} 
pants are male. Some women also joined but are not too active. None of the practitioners consider themselves to be New Agers. In my thesis, I use the term 'Muslim New Agers' just like the term 'Shiite-Muslim' or 'Sunni-Muslim' were used in signalizing their identity. ${ }^{12}$

According to Abu Fatiah Al-Adnani, the Shamballa community in Jakarta calls them self as New Agers. Moreover he said that Shamballa is part of Reiki, contains supernatural powers and is closely related with supernatural creatures in practicing the ritual. Later, he stated that Shamballa Reiki has many contradictions with Islam. New Age is considered as 'sects' or religion's deviation by some Muslim scholars in Abu Fatiah AlAdnani's book, 'Kaki Tangan Dajjal Mencengkeram Indonesia' (Dajjal clutching Indonesia), which is published by Group Analyze of Kitab ArRisalah from Ngruki-Solo, Indonesia. Though they don't consider it as part of the New Religious Movement, they said that New Age has new perspectives and new approaches which are far away from Islam, for example are their belief in reincarnation, using Zionism's symbols and belief in Wahdatul Wujud or Monism. Al-Adnani also condemned as the Perennial of New Age as 'Spiritual yang tidak terikat dengan Syari'at' or spirituality that has not been mentioned as the part of Islam. ${ }^{13}$

Muslim New Agers are Muslims who deal with New Age things. This New Age movement seems to have a good relationship with these

\footnotetext{
${ }^{12}$ In his research, A. Budiyanto use the term, "Islam Buddho." He explained that there might be a stereotypical nickname to named Muslim Reiki practitioners (here, my research also about these kinds of people) in Indonesia as Islam Buddho. But since the practices of reiki, yoga, kundalini and meditation are part of Hindu and Buddhis traditions, so I guess it will be makes sense if A. Budiyanto want to named the 'Muslim Reiki practitioners' as Islam Buddha. He also considered that Reiki technique might be related, historically, with Islamic Sufism.

${ }^{13}$ Moreover, Sufism according to Ahmad bin Abdul Aziz al-Hushain and Dr. Abdullah Mustofa Numsuk book's (2004) entitled Kesesatan Sufi, Tassawuf, Ajaran Budha! (The Deviance of Sufi, Tassawuf [is] the teaching of Buddha!) is highly influenced by Buddhism.see also Abu Fatiah AlAdnani, Kaki Tangan Dajjal Mencengkeram Indonesia, Solo: CV Arafah Group, 2007, 163.
} 
Muslims, though in some parts it has created tension between radical/ puritan Islam and Muslim New Agers. I use 'Muslim New Agers' to identify Muslim believers who are practicing the New Age practices in their religious life. In Pekalongan, Shamballa is combined with Sufism or vice versa. According to the main person in Jamaah Kraton, it has a historical relationship with Islam-Sufism. Therefore, I consider the term Muslim New Ager for Shamballa practitioners to be applicable.

The city of Pekalongan was chosen as a research area because in Pekalongan there are some practitioners of Shamballa Multi Dimention Healing (Shambhalla MDH) which is related to Sufism, Theosophy, and Reiki. They modified Shamballa, combined it with Sufi meditation (dzikir and shalat) and created a new ritual, new methods, and even new name - Jamaah Kraton. The key person of Jamaah Kraton is a Muslim Reiki practitioner and is of Arab descent. Though Jamaah Kraton is not dominated with Arab descent, many main persons in Jamaah Kraton are Arab.

In regards to the background of the problem expressed above, my research is based on the current phenomenon of Islam engagement with New Age in Java such as Shamballa MDH Pekalongan. The research will focuses on several events of Shamballa Multi Dimention Healing. The first event is Full-moon Meditation and the second is Weekly Meditation. There are several events such as the first attunement, the Waisak in Bali with Grand Masters, the meeting with Lia Aminuddin Salamullah, and the occasional meditation (such as meditation in Isra' Mi'raj and Nisf Sha'ban) which can help to capture their essential universal character as Muslim New Agers.

In order to understand Muslim New Agers's goals, one must understand the central ideological concept of New Age, because the universal attitude of a Muslim spiritualist is a way to tell the world that their 
Muslim identity as the part of Islam which is able to mingle with all faiths and religions. What happened in Jamaah Kraton is they were able to run their activities in the middle of what others may see as a 'cold war' between the adherents of Jamaah Kraton and the ones who reject their activities. That is the example of external conflict and for internal conflict, which arise in the question about their identity. Does New Age philosophy and teachings affect their Islamic identity? Does the New Age they adopt create the conflict within itself? In regards to the background of the problem expressed above, there are several questions that need to be answered. They are: why do this people join Jamaah Kraton - the New Age-like Community? How does the New Age affect their identity as a Muslim?

\section{The fascinating teaching and the charismatic leader}

There are factors which made these people joined Jamaah Kraton, they are: the fascinating teachings and the charismatic leader. The main teaching of Shamballa is channeled by Haridas from Ascended Master St. Germain. Many people I've interviewed mention about how lucky they are to find such place. They can share most anything about life and spirituality.

Believing what a Hindu believed is something common for Jamaah Kraton. They had use the Hindu concept of Kundalini, Avatar, Karma, and now, reincarnation. They even enjoyed a documentary film about the Jesus journey to India. They commented, 'Could have happened. No one knows. ${ }^{14}$ The member of Jamaah Kraton believes in almost all possibilities about reincarnation and such. They believe in reincarnation, past life regression, the power of intuition and the vision. They never said that 'such teaching' is wrong and 'such' is right. They do this

${ }^{14}$ Interviewed with Musa and Helmy, Yogyakarta, in May 2007. 
because Imuh taught them to be so, which is a must for them to have a value of seeing others which have different life's philosophy not as the others. As Imuh said, 'the most interesting part of understanding reincarnation is we must pay attention about the karma. This will make us become a wise person and less harm to other beings.'

The other reason why my respondents joined Jamaah Kraton is because they saw Imuh as charismatic person. Imuh had a wider point of view in seeing things. There were stories in which he accepted people from different backgrounds and he pleased to accept them all. They know who Imuh is, so they will not afraid that Imuh will teach heresy. Moreover, they know Imuh's family back to his grandfather. All of them said that Imuh and his grandfather were alike. Both of them are good persons and agreement special abilities related to the world of spirituality. Imuh's personality impressed many Jamaah Kraton members who seen him as a wise person.

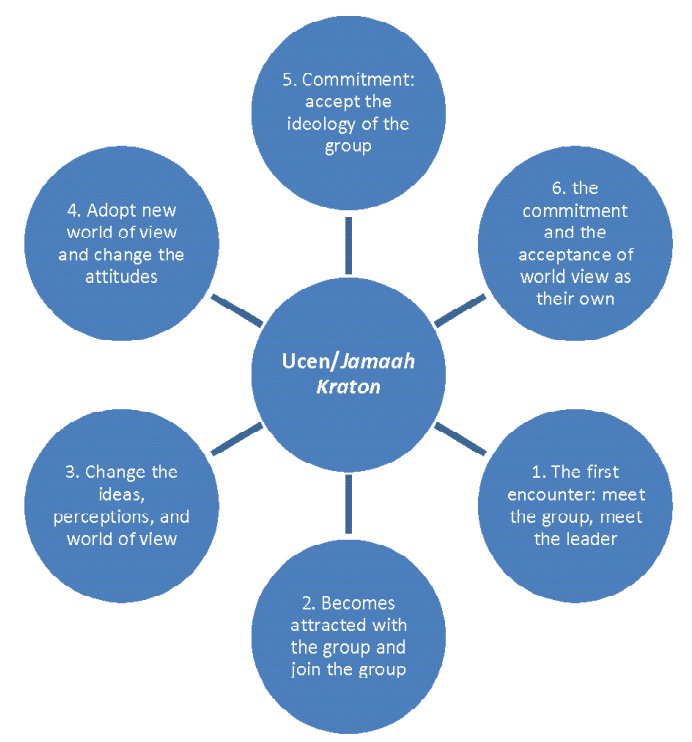

Picture 1: This shows the process between the individual when they meet the leader and the group of Jamaah Kraton 
The charismatic leader creates charismatic commitment. As Lalich stated that participant's involvement in such group is based on their attraction to the leader ideas and it continues in changing their point of view. ${ }^{15}$ There are, perhaps, many reasons for someone to join Jamaah Kraton, but this 'charismatic leader' reason is the $2^{\text {nd }}$ most common reason I had during my interviews with my informants. If we took example from the Nikmah's family, we can see such pattern matched with the scheme of how Ucin's first met with Imuh and his gathering. Most of my informants had the same experiences.

\section{The identity of Jamaah Kraton}

During my research, Pekalongan celebrated several events such as Pekalongan Aniversary in April $1^{\text {st }}$, Pek Cun (Chinese ritual of thanksgiving to the Earth in the Sea or Sedekah Alam), Nisf Sha'ban (Sha'ban $15^{\text {th }}$; Sha'ban is an Islamic month in Lunar Calender); Haul of Sapuro (the commemorate a great arab scholar, Al Habib Achmad bin Abdullah bin Thalib Alatas; Commemorate of Imam Mahdi for Shiite Muslim in Pesantren Al-Hadi, and Indonesia Independence Day (August $17^{\text {th }}$ ). The city shows its identity of many culture lies within. Though the town is Muslim in majority - and named as The Santri Town, it is not Muslim dominated. In the area of The Bridge of Loji (brook or Jembatan Loji) lies a church, mosque and kelenteng (a place to pray for BuddhistChinese people). It was said also that Kospin Jasa (Koperasi Simpan Pinjam Jasa) which still exists now is a living proof of the existence of a very strong tolerance in Pekalongan. The people of who involve in Kospin Jasa are from many different backgrounds and ethnicities, Javanese, Chinese, Arab, and even other ethnicities outside Java.

${ }^{15}$ Janja. .Lalich, Bounded Choice: True Believers and Charismatic Cults, Berkeley: University of California Press, 2004, 233. 
Pekalongan has Chinese, Arabian culture, and even it has Hinduism culture in the village of Lingga. In order to explain the town where Muslim New Agers performed their ritual of meditation, one must know the history of the town, the Muslim, and the people.

There are many tariqah (Sufi movement) in Indonesia, and Pekalongan has the most followers of Sufism after Aceh. The most favorite one is Tariqah Qadiriah from Syech Abdulkadir Jaelani and we can find many of his petilasan here. It is not surprising when I went with someone to read yasinan (the Verses of Yasin in the Quran) and prayer every Thurday at his house after Maghrib (evening time), we read al-Fatihah (the first chapter from the Quran) for Abdulkadir Jaelani. ${ }^{16}$ Once I asked, and he said, that he is the most important person in Islamization in Pekalongan.

Moreover about spirituality in Pekalongan, the trace of Theosophy can be found in Pekalongan. There is an article in the Internet said that Theosophy arrived in Pekalongan around 1881. This article is also used by several Islamic scholars to prove the movement of Freemasonry in Indonesia. The article said that The Theosophist Journal which published in New York told that Blavatsky asked Baron van Tengnagel to build a lodge ( $l o j i)$ - a prayer house for Freemansory in Pekalongan. Since 1868, the status of Pekalongan was changed from 'village' to 'town' and known as Muslim town in Central Java. The Lodge was built

\footnotetext{
${ }^{16} \mathrm{New}$ Age is a cultic milieu which consists of a blend of eastern mysticism, neo-paganism, western esotericism, occult phenomena, dealt with charismatic personality who is divinely inspired, spirits, angels, elementals, channeling, aura, acupuncture, past-life therapy, soul travel, Reiki, aromatherapy, rebirthing, reincarnation, holistic health, green movement, and as social phenomenon, self spirituality and human potential movement are the keys. Brian added that Hannegraaff and Heelas tend to view Neo-paganism as part of New Age Movement since they have same background on rejection of materialism world and orthodoxy of a religious institution of Christianity. See Brian Morris, Religion and Anthropology: A Critical Introduction, New York: Cambridge University Press, 2006, 304-308.
} 
in 1883, but it provoked a reaction from society related with their (the Freemasonry) ritual of calling the spirit. For that reason, the people named the lodge, Gedong Setan (Satanic Building). ${ }^{17}$ We cannot find the building now, but it was believed that the name of Jembatan Loji or the Bridge of Loji was taken from the name of Gedong Setan (Loji) which it means the place was there. The internet sources told that the building was burned and Theosophy moved to Batavia and many other places which were more suitable. Nowadays no one knows wether the existence of the Loji (Gedong Setan) in Pekalongan is a hoax or a fact. I haven't found any clue about it except the news in internet and some books which mentioned the existence of Theosophy and Freemason in Tegal and some older pictures of an old building from the colonial era. But it said that there was an Arab whom joined Theosophy class in Jakarta and he was the only Arabian student at his time. ${ }^{18}$

Jamaah Kraton formed from conventional Sufi Group discussion into more New Age-like community. For Imuh, Herkolis, Ucen, Amank, Zen, Musa, Nikmah, and many others, they face many issues that form their cultural identity. Jamaah Kraton is a meditation and discussion group run by several people in Pekalongan. The group was founded by Imuh - a 42 years old Arabian man whom also a healer, an herbalist, an acupuncturist, a counselor, and a businessman. Most of my respondents are the Arab but not all the member of Jamaah Kraton are the Arab descent. The leader of Jamaah Kraton, the first generation of this group discussion and all the committee when Shamballa had workshops were dominated by the Arabs who were active in Jamaah Kraton group discussion.

${ }^{17}$ Marilyn Ferguson, The Aquarian Conspiracy: Personal and Social Transformation in the 1980s, Los Angeles: J.P Tarcher, Inc., 1980, 18.

${ }^{18}$ See Sukidi, Wisata Spiritual Lintas Agama, Jakarta: Gramedia, 2001, 55-57. 
Jamaah Kraton called themselves as Para Pekerja Cahaya or Light Workers. In explaining about Jamaah Kraton, means we were talking about the history of the group discussion, the Leader, and the members. The explanation about Jamaah Kraton will explain about why the group discussion formed and why they joined it. The Sufi Discussion Group was formed by Imuh or Bib Muh about ten years ago in Pekalongan. There were only few people who joined the group that time and the discussion was attended only by several people most of which were Imuh's best friend. The next, as more people became interested and heard about the prayer (shalat tasbih, shalat Hajat, and shalat taubat) and the discussion, the jamaah members were increased.

Every $15^{\text {th }}$ of the Lunar month, Jamaah Kraton held Full-Moon Meditation and at that time, about 100 people gathered in one place to have their meditation together. For several years, they had it in the field yard behind G-Net, but several times, in this year, since Waisak 2008, they tried new place to meditate in Slamaran beach. The leader will send short message (SMS) to the jamaah, and asked them to come in the place which is ready to had meditation. Jamaah Kraton also believes the existence of UFOs and Aliens. Every Jamaah Kraton's meditation always 'channeled' most with Shalawat Nabi. Channeling is not a new phenomenon, since it has different any other name such as 'revelation' and 'mediumship', It is a process in which information is accessed and expressed by individuals convinced that the source is not their ordinary consciousness. The material can be transferred via telepathy, automatic writing, or directly through the vocal cord of the channel, which sometime the voices quite different than the ordinary voices of the channelers. ${ }^{19}$

\footnotetext{
${ }^{19}$ "Spiritualitas Feminis dalam Gerakan New Age", Jurnal Perempuan, no. 20 ( 2001), 7-21.
} 
The teacher of Muslim New Age of Jamaah Kraton combined various traditions in their courses. He adopted Hindu ideas about chakras, Jewish tradition about Merkabah, and New Age-like themes of Atlantic, UFO, mixed traditional Chinese medicine with Reiki Shambhalla, and with their philosophy - their perennial philosophy which means that they believe that the diversity of religious tradition essentially refers to the same spiritual truth. The problem of identity arose here. An Arab, a Muslim, an Indonesian who lived in Pekalongan, a Muslim town, practicing yoga, fullmoon meditation, active in Merkaba Meditation, and simply a New Ager.

Friedman gave samples of Islamization in Africa. There, the elites of the Sahara consider themselves as Arabs from Mekkah, so they practiced foreign identity with importing symbols, cloth, and religion outside their country. These people did the same thing. If common knowledge had considered chakra from Hinduism, and Merkaba from Judaism, then these people also practiced foreign identity importing symbols from religions outside their country. The interesting part is they had evidence from their own perspective that matched with their Islamic identity. For them, the concepts such as 'Higher self', 'Metatron', Merkaba, are not a new or re-new concept in Islam, but they are as much as old as the tradition itself. In short, for them, Islam had the concepts also, but with different words and language.

According to Friedman, there are two types of cultural identity. The first is lifestyle. It has no legitimation in history and is also the most modern and the easiest to choose by individuals. The second is ethnicity, which is a way of looking at the difference between others and it is usually connected with 'blood'. Ethnicity usually described as a common tradition or race. ${ }^{20}$ Here, we can see whether New Age identity in

${ }^{20}$ See JD. Howell, "Islam, The New Age and Marginal Religious in Indonesia: Changing Meanings of Religious Pluralism", The Cesnur 2003 International Conference, Vilnius, Lithuania, 2003. 
Jamaah Kraton is part of the lifestyle or had a correlation with ethnicity or even other identities such as their Islamic identity. In short, what has formed Jamaah Kraton is they consider religion to be a part of a life style. Also, there were many kinds of traditions can be use to meet God. They don't consider Merkaba and Chakra as haram (forbidden) to believe in as long as it gives benefits to their spiritual life. For these people, meditation is a way to meet the higher self, discovering inner self, and is a skill which should be mastered for Muslims because it is the basic teaching which the prophet Muhammad had before he had messages to perform Shalat.

They will not change their religion. They choose to stay Muslim, but they consider that all religions lead the same path. They felt Islam had satisfied them and there is no reason to change their religion. What makes them to try other traditions outside their religion is because they seek more experiences, and they don't consider Merkaba, Metatron, Higher Self as things that don't fit with Islam. In fact, the collaboration between many traditions made them enjoy Islam.

\section{Evaluation: the Muslim new ager's hybrid identity}

As we know the impact of integration on the Arab community can be seen in their extrinsic (physical) culture such as rites (rite of passages and rites of Islamic holy days), traditions (food, building, language, art, and medicinal treatment), values (education and women's position), and symbols (dress and mosque). The complexity of Jamaah Kraton's identity as Muslim New Age practitioners has been added their ethnic identity as an Arab.

Indonesia is a multi-culture country because of the many ethnic groups in plural societies. In Indonesia, the Identity Card or KTP shows a person's religion. Even in some cases, people have to pretend as a 
Muslim or Christian just because of their belief were not one of five professedly religions in Indonesia. The important of religious identity in Indonesia also can be seen when we want to fill the Hospital form where we can find column which asked about our religion. Again, the religious view we put in Identity Card can be very different with religious identity we had when we face on some religious problems.

Negotiate the problem

It is commonly held that second-third generation immigrants in Indonesian cities of Arabian descents experience identity problems because of the live of many cultures. They (Arabian descents) have their own cultures and values which also contribute to the culture of Nusantara Indonesia. They also want to keep the cultures and values alive, otherwise they will not joined organizations such as Arabithah and Al-Amin which is exclusive enough. Such ethnic organization can be regarded as a strategy of defensive response against discrimination and the refusal of the majority to allow them to assimilate. They may continual to be loyal to their grandparent's ethnic category, although they are conscious of being culturally different or spiritually different. They have no political reason. They may act that way because they find it inherently meaningful not for political reason. None of their activities have implicit assumptions from economic motives. But one reason which seems to be seen as political reason that they want to reintroduce Islam as Rahmah li al-'alamin (Islam for all).

Moreover, Arabian-Javanese or Arabian-non Arabian descent marriage sometime perceived as a mixed marriage; and in a mixed culture there are always tension between individual and the elder. Kinship remains an important principle for most societies in the world. If mixed culture married has become a problem for the Arab descent in Indone- 
sia, so will inter-religious marriage. This also happened in Jamaah Kraton community. Mixed culture married happened, some people agree and some people don't. But it will not affect anything because once marriage happened, it will soon be forgotten. People will soon understand that the marriage was only a mixed culture married. It will be different if the marriage is an inter-religious marriage. Most of respondents disagree. In some point, they considered that all religions are true and from the One Divine, but in another point which related to kinship, they don't want to married with different religion in the name of 'if we can married people from same religion, why not married them instead of married with people from other religion and started to have conflict with family and environment.'

From previous chapters I defined that Muslim New Agers are people who performs New Age-like ritual and use terms such as channeling, attunement, Metatron, UFOs, Full-moon and Merkaba Meditation. They mixed two different rituals and belief systems and practicing it as part of their Islam identity. The lifestyle, the religion, the culture, the ethnicity, and the tradition of the Pekalongan mingled very well when Tasawuf met with New Age-like rituals which Shamballa brought to the Muslim Town, Pekalongan. These could happen because the Leader, Imuh and the teachings are also interesting. In doing it, there are some rituals which contrast with their Islam and Arab identity. When conflict happened, they negotiated. The movement is strong in both religious character and their politic to repair their Islamic identity which according to them, it had been destroyed by negative images.

\section{Passing Over}

From my perspective, these people are not pluralists, they are inclusive -the moderate one. They disagree with kawin beda agama (mar- 
riage between different religion), and they don't want to change their religion. It can be seen from their opinion which said that they disagree if someone in their family changes religion. For them, it is okay one wants to become Sunni or Shite, but not okay if he/she become Ahmadiyyah which based on their knowledge, the Ahmadiyyah's last prophet is not Muhammad.Though they disagree to change their faith, they felt that Muslim should not consider Ahmadiyyah's followers as infidel.

There are many reasons why they joined Jamaah Kraton. First, I thought the reason why this Arab descent joined Kraton was because of the leader is an Arab. Then I found that it was not because the leader only, but the teachings too and perhaps it can be found that there are more reasons than the reasons I have found. Since this is about someone's life experiences, there are many reasons behind every action. Identity is continually being constructed through experience of living in and interacting with the world. Jamaah Kraton had done this. They interacted with the globalization and modernization world. They read many sources of New Age articles in Internet, they read many spiritual books, met Sufism and fall in love at first sight. Bowie added that in some instances identities were being negotiated and defined (2006:68). We can see how Jamaah Kraton's Islam and Arab identity met with New Age spirituality, and it were reshaping their value system. They opened themselves to New Age discourses and practiced it in everyday life.

As Eriksen concluded, culture is faithful to one's ancestors and the past; religion may or may not play an important role there. ${ }^{21}$ Some movements were not only religious in character, but also respect both

\footnotetext{
18.

${ }^{21}$ Ahmad Nurcholish, "Agama Baru itu bernama New Age", Majemuk. No. 20 (Mei-June 2006.),
} 
for politics and identity. As I said earlier, Jamaah Kraton has both. Jamaah Kraton wants to change the negative image over Arabian descents and Islam as their religion. They also can be considered as people who are 'betwixt and between' which tend to mess up any system of contrast in ethnic classification. In another words the are considered as 'neither nor' or 'both-and' depending on the situation and the context.

From my perspective, these people are not pluralists, they are inclusive -the moderate one. They disagree with kawin beda agama (marriage between different religion), and they don't want to change their religion. It can be seen from their opinion which said that they disagree if someone in their family changes religion. For them, it is okay one wants to become Sunni or Shite, but not okay if he/she become Ahmadiyyah which based on their knowledge, the Ahmadiyyah's last prophet is not Muhammad.Though they disagree to change their faith, they felt that Muslim should not consider Ahmadiyyah's followers as infidel.

In Dunne's terms, these people are 'passing over'. We have seen that the New Age movement of the late twentieth century has reminiscent of the Theosophy Society, such us Reiki Shamballa which Jamaah Kraton adopted in their earlier Sufism form. When Shamballa came, the problem will of course impact their identity as Muslims. For that case, there is a way to understand what happen, by using the term which Dunne called 'Passing Over' and 'Coming Back' where people used to have a spiritual experience in other religions, and then they come back to their own religion with a new paradigm, point of view, and enriched spiritual experience within their own faith. ${ }^{22}$ This shaped their identity as a Muslim, and an Arab.

\footnotetext{
${ }^{22} \mathrm{JD}$. Howell, "Islam, The New Age and Marginal Religious in Indonesia: Changing Meanings of Religious Pluralism", The Cesnur 2003 International Conference, Vilnius, Lithuania, 2003.
} 


\section{Hybrid identity of Jamaah Kraton}

The people of Jamaah Kraton as the Muslim New Ager faced problems with their identity. They faced contradictions with the Muslim majority, and their ethnicity. Lately, they found negotiation within their passing over experience and the result is hybridity - a feeling of enjoyment of a mixture the cultures and religious traditions. As a result, others may see them as part of syncretism where they put Hinduism, Buddhism, Judaism, Christianity, and Islam in one big bowl of particular mixture traditions.

The messages they carried with their New Age Muslim identity are that in the world where Muslims and Arabs always had conflict with others, they want to show that Islam had made their Arab identity as something not to be proud with or to be scared of (related with terrorism). They also show it in the case when Lia Aminuddin (or Lia Eden) with her spiritual movement (It was Salamullah at the time) is banned by the Islamist community and government for condemning Islam, Jamaah Kraton enjoy the meeting with her and considered Lia and her jamaah as 'The Seeker' like them. They welcomed them. When Lia told Imuh that 'no habaib accept me like this', they had succeeded to introduce to the world that Islam and their Arab identity are something that they should not be afraid of. It was the same message they carried when they attended the Waisak (the Full-moon Meditation) in Bali with Hari Baba (John Armitage) and his fellows; to introduce that Islam and Arab are not identical with violence.

Marcia Hermansen, in her article titled Hybrid Identity Formations in Muslim America (2000), has separated American-Sufi ideology into two distinct groups: Hybrid and perennial. Hybrid Sufis are those who have performed the practices and beliefs of traditional Islam with those of their American context. Most hybrid Sufis are immigrants to the United 
States from countries such as Morocco across the Middle East to Iran, Pakistan, India, and Malaysia and most have come to Sufism from more traditional Islamic beliefs. Perennial Sufis, on the other hand, have taken a more universal approach to religion, viewing all major world religious beliefs are leading to a common center. Unlike most hybrid Sufis, perennials are usually of European-American descent and typically come to the religion from Western religious beliefs, namely Christianity. ${ }^{23}$

Hybridity occurs as a result of cultural suppression, political and economic control in post-colonial societies. It also happens when 'settler-invader' make contact with indigenous people and 'force; them to assimilate with new social patterns. The continual contact between the settler and the invader also gave impact to the process of Hybridity. ${ }^{24}$ Moreover, Jamaah Kraton gave a clear description about Bhaba's statement of how culture supposed to be understood, which is 'never unitary in themselves, nor simply dualistic in relation of Self to Other ${ }^{25}$ by believing that all cultures can be the genuine. ${ }^{26}$

I found that the problem within the Arabs related with their identity as non-pribumi, they able to mingle with others because Jamaah Kraton taught them to listen to other wisdom though the wisdoms are not from 'para Habaib' or any other Arab scholars (their ancestors). I saw that Jamaah Kraton as a new community where it combined all traditions with something new or re-new, then it produced something newer.

\footnotetext{
${ }^{23}$ See further information in 'Laporan Kebebasan Beragama Internasional 2006' which is taken from Biro Demokrasi, Hak Asasi Manusia dan Perburuhan.

${ }^{24}$ Channeled at March 16, 1996 by HariDas from Ascended Master Germain and rewrote in guide-book of Shamballa Multi Dimension Healing Level 1.

${ }^{25}$ David V. Barret, Sects, 'Cults' and Alternative Religions: a World Survey and Sourcebook. London: Blanford, 1996, 230.

${ }^{26}$ They called themselves as Pekerja Cahaya or in international New Age term is known as Light Workers.
} 
But it doesn't mean that it has nothing to do with personal identity of someone or inner selves. Someone's personal identity cannot be separated from social identity.

Therefore I had my courage to say that when several people in Jamaah Kraton had 'pass over' in their spiritual life, it means that all Jamaah Kraton's member had done the same experience and so with other Muslim New Agers all over the world. Once they negotiate to face their religious identity problem, they dare to passing over to other religious experiences and if they enjoyed, it shaped their new religious identity which accept other comfortable identity as their own.

\section{An inclusive-universal religious identity}

Refers to social identity theory about three perspective of seeing identity, when a group of people in a certain culture has bad image, they will do whatever they can do to recover their image or their identity will remain exist. Since the Poso Conflict in 1999, Islam became more identical with the world of terror. ${ }^{27}$ Extremist interpretations of Islamic teaching are frequently taken by other religions to express the general beliefs of all Moslems. The extremist development reflected in Indonesia, where there has been a dramatic increase in the number of terrorist bombings in the post-Suharto era until the succeeded in arresting bombers Imam Samudra, Ali Imran, and others as terrorist in the name of religion. This is what makes Jamaah Kraton choose to become part of The Light Workers which has 'a universal religious iden-

\footnotetext{
${ }^{27}$ In his research, A. Budiyanto use the term, "Islam Buddho." He explained that there might be a stereotypical nickname to named Muslim Reiki practitioners (here, my research also about these kinds of people) in Indonesia as Islam Buddho. But since the practices of reiki, yoga, kundalini and meditation are part of Hindu and Buddhis traditions, so I guess it will be makes sense if A. Budiyanto want to named the 'Muslim Reiki practitioners' as Islam Buddha. He also considered that Reiki technique might be related, historically, with Islamic Sufism.
} 
tity.' But what makes different is Jamaah Kraton still hold their religion and tradition such us in marriage, which is they would never choose spouse with different religion though they consider all religions leading the same path.

\section{Bibliography}

Al-Adnani, Abu Fatiah. Dajjal Sudah Muncul di Khurasan. Solo: CV Arafah Group, 2006.

Al-Adnani, Abu Fatiah. Kaki Tangan Dajjal Mencengkeram Indonesia. Solo: CV Arafah Group, 2007.

Ashcroft, Bill, Gareth Griffiths, and Helen Tiffin (eds.). The Post Colonial Studies Reader, USA, Canada: Routledge, 1995.

Barret, David V. Sects, 'Cults' and Alternative Religions: a World Survey and Sourcebook. London: Blanford, 1996.

Bhabha, Homi K., "Cultural Diversity and Cultural Differences", in Bill Ashcroft, Gareth Griffiths, and Helen Tiffin (eds.), The Post Colonial Studies Reader, USA, Canada: Routledge, 1995.

Budiyanto, A., "The Dynamic of Javanese Religious Orientation", thesis at Centre for Religious and Cross Cultural Studies UGM, 2004.

Eriksen, Thomas Hylland. Ethnicity and nationalism: Anthropological Perspectives. London: Pluto Press, 2002.

Ferguson, Marilyn. The Aquarian Conspiracy: Personal and Social Transformation in the 1980s. Los Angeles: J.P Tarcher, 1980.

Friedman, Jonathan. Cultural Identity and Global Process. London: Sage Publications, 1994.

Hermansen, Marcia, "Hybrid Identity Formations in Muslim America", Muslim World, Vol. 90, No. 1 (2000): 158-198. <http:// web.ebscohost.com/ehost/detail?vid=4\&hid = 2\&sid=d0de1824- 
7297-4315-87d8-70be332b1ecf\%40sessionmgr9> accessed 12/ $1 / 2006$.

Howell, JD., "Islam, The New Age and Marginal Religious in Indonesia:

Changing Meanings of Religious Pluralism", in The Cesnur International Conference. Vilnius, Lithuania, 2003.

Langone, Michael D., "Secular and Religious Critiques of Cults: Complementary Visions, Not Irresolvable Conflicts" taken from the website: http://www.csj.org/infoserv_articles/langone_michael_ secularandreligiouscritiquesofcults.htm (22 November 2006).

Melton, J. Gordon, Jerome Clark and Aidan A. Kelly (eds.). New Age Almanac. Detroit, Michigan: Gale Research Inc., 1991.

Morris, Brian. Religion and Anthropology: A Critical Introduction. New York: Cambridge University Press, 2006.

Nurcholish, Ahmad. "Agama Baru itu bernama New Age", Majemuk. No. 20 (Mei-June2006).

Poewe, Karla and Hexham, Irving. New Religions as Global Cultures: Making the Human Sacred. USA: Westview Press, 1997.

Ricklefs, M.C. Sejarah Indonesia Modern 1200-2008. (translation from 'A History of Modern Indonesia since c. 1200). Jakarta: Serambi, 2008.

Sukidi. Wisata Spiritual Lintas Agama. Jakarta: Gramedia, 2001. Tollenaere, Herman A. O de. The Politics of Divine Wisdom. Leiden: Nijmegen University, 1996. 